University of Nebraska - Lincoln

DigitalCommons@University of Nebraska - Lincoln

Faculty Publications from the Harold W. Manter Laboratory of Parasitology

$12-1950$

\title{
Observations on a Cyclic Decline of Lemmings (Lemmus) on the Arctic Coast of Alaska during the Spring of 1949
}

Robert L. Rausch

University of Washington, rausch@u.washington.edu

Follow this and additional works at: https://digitalcommons.unl.edu/parasitologyfacpubs

Part of the Parasitology Commons

Rausch, Robert L., "Observations on a Cyclic Decline of Lemmings (Lemmus) on the Arctic Coast of Alaska during the Spring of 1949" (1950). Faculty Publications from the Harold W. Manter Laboratory of Parasitology. 501.

https://digitalcommons.unl.edu/parasitologyfacpubs/501

This Article is brought to you for free and open access by the Parasitology, Harold W. Manter Laboratory of at DigitalCommons@University of Nebraska - Lincoln. It has been accepted for inclusion in Faculty Publications from the Harold W. Manter Laboratory of Parasitology by an authorized administrator of DigitalCommons@University of Nebraska - Lincoln. 


\title{
OBSERVATIONS ON A CYCLIC DECLINE OF LEMMINGS (LEMMUS) ON THE ARCTIC COAST OF ALASKA DURING THE SPRING OF 1949
}

\author{
By Robert Rausch*
}

$\mathbf{T}$

Vue importance to the biotic community of various species of lemmings in arctic and subarctic regions has long been recognized, but there is little known about the ecology of these mammals. During the spring of 1949 the writer had the good fortune to observe a cyclic decline in the population of the brown lemming on the Arctic Coast of Alaska. Observations were made during the peak density preceding this decline (Fig. 1),

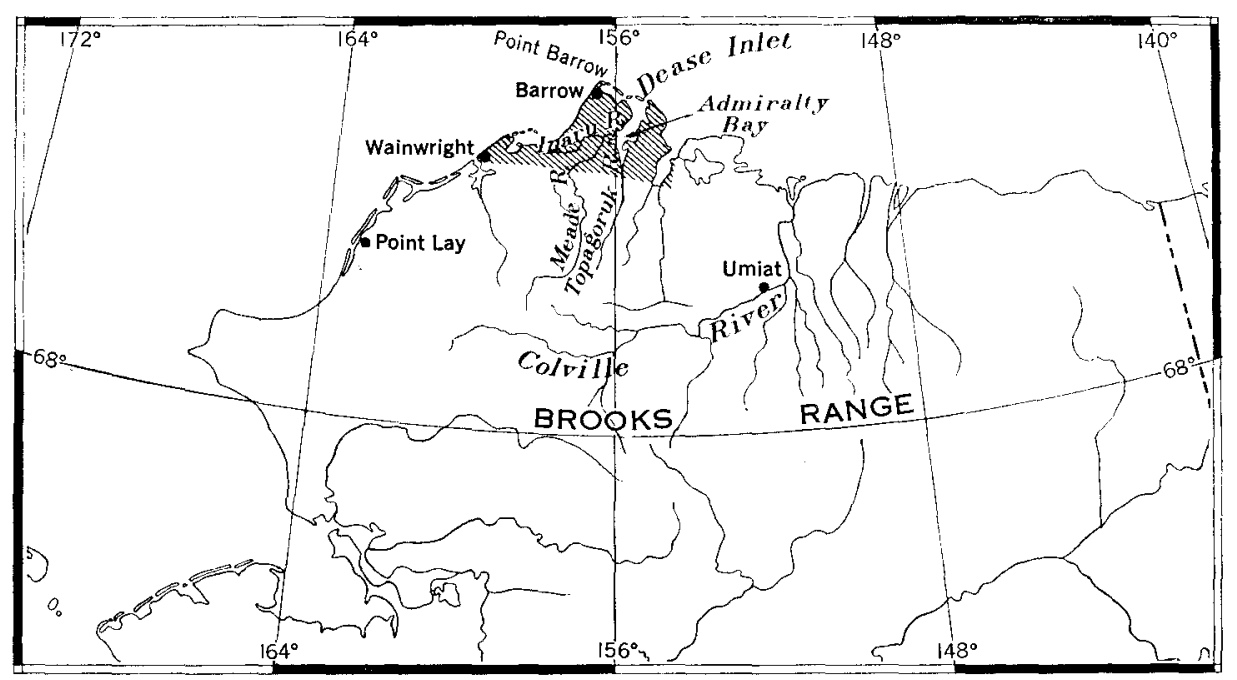

Fig. 1. The shaded area indicates the known extent of lemming density during the spring of 1949.

and were continued for more than a year subsequent to it. It is the purpose of this paper to present the results of these studies.

Two species of lemmings occur on the Arctic Slope of Alaska; they are the collared lemming, Dicrostonyx groenlandicus rubricatus (Richardson), and the brown lemming, Lemmus trimucronatus alascensis Merriam. While both of these were observed during the course of this study, only the brown lemming was present in great numbers. However, both species were affected by whatever factors were responsible for the mortality which caused a precipitous decline in lemming numbers.

The writer began observations on lemmings in the Point Barrow region on 22 March 1949, when an effort was made to secure some of the rodents for parasitological examination. Field observations made over this period are briefly presented here. This opportunity is taken to express appreciation to the Arctic Research Laboratory, Office of Naval Researchi, whose cooperation made this work possible.

*Parasitologist, Arctic Health Rescarch Center, Anchorage, Alaska. 


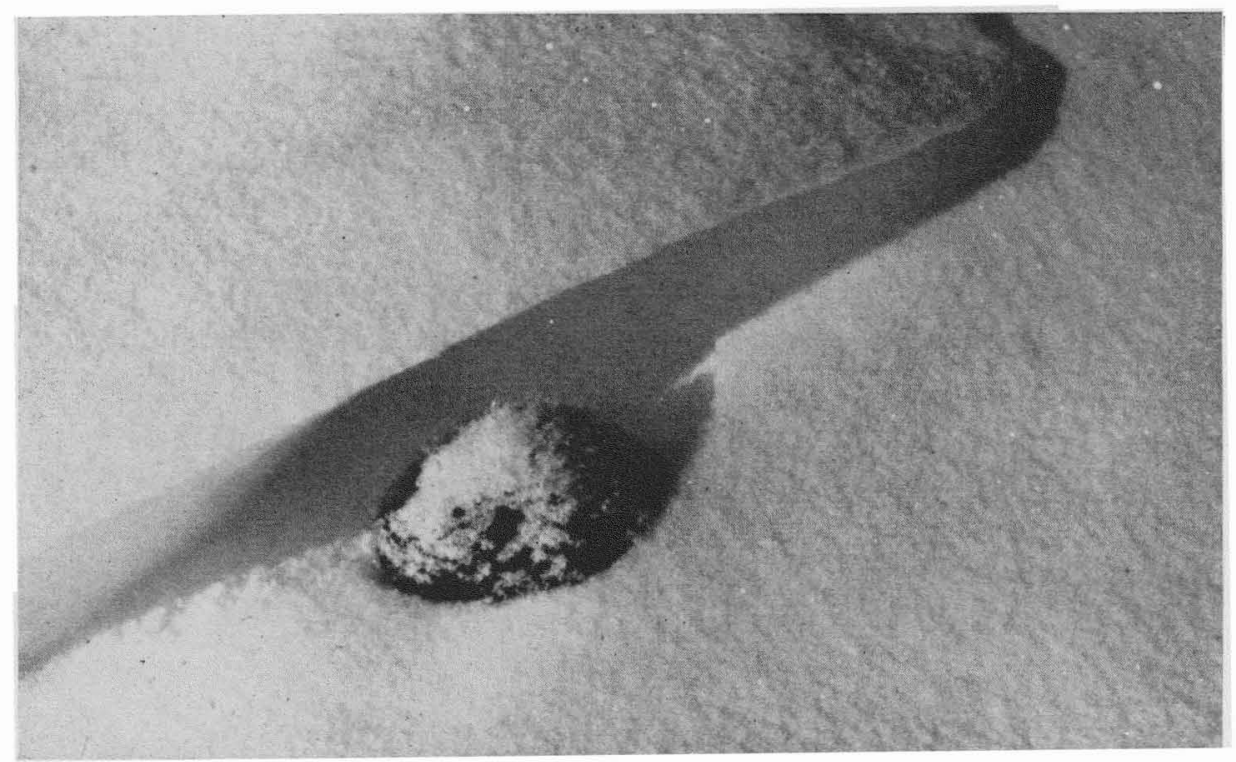

Fig. 2. Brown lemming dead on the snow surface, as commonly observed preceding the abrupt decline of the early spring of 1949.

Observations During 1949

On March 22 lemming tracks were numerous in the vicinity of Point Barrow. These tracks emerged from burrows in the snow, and practically all were made by Lemmus. Such snow tunnels apparently were used but once, for additional tracks were not noticed coming from them, and attempts to trap lemmings by making runway sets nearby were unsuccessful. The animals left the security of the snow to wander about on the crust. Whether they survived is not known, but later observations indicate that many did not. For several days following March 25, an effort was made to trap lemmings by digging a trench down to the tundra, wherc baited snap-type traps ${ }^{1}$ were set near the sub-snow space. Lemmings were numerous, judging from the abundance of fresh droppings under the snow. This method failed entirely even though, when light snow-falls covered the area, lemming tracks were often observed near the traps. Subsequent observations indicate that lemmings are best trapped where unbaited runway sets can be made.

On March 26; following a period of high wind and cold weather, three brown lemmings were found dead on the surface of the snow, and from this time on numerous specimens were secured by searching for them on the tundra where their dark colour in contrast with the snow made them visible for a considerable distance (Fig. 2). The first snowy owl was seen on March 28.

A total of 46 lemmings was obtained in this manner prior to May 12, after which living animals were occasionally captured. The animals found dead weighed from 13 to 75 grams, with an average weight of 44 grams. Most of these animals were juveniles or subadults.

${ }^{1}$ Peanut butter was generally used as bait. 
Four snowy owls were seen on April 4 near Point Barrow, and several others were seen the next few days during the course of a trip along the Inaru, Meade, and Topagoruk rivers, covering a distance of about 150 miles. On this trip a single brown lemming was captured (April 4), and a collared lemming was found dead on the surface of the snow (April 15). No other lemmings were seen.

From April 24 to May 7 the writer worked farther inland, beyond the limits of high lemming density. After May 7, upon return to the lemming area, dead brown lemmings were found increasingly more often on the snow surfacc. About May 15 the effect of the spring thaw was becoming apparent, and bare patches of tundra could be seen in favourably located areas. By May 17 the melting was appreciable, and it was only then possible to gain a real impression of the actual abundance of the brown lemmings. Their tracks became increasingly numerous in the snow surrounding the bare patches of tundra, and this snow was also honeycombed with their tunnels. The lemmings were very active around the open areas, but ran beneath the snow at the slightest provocation. Arctic foxes circulated from one of these snow-frec arcas to another in their attempts to capture lemmings, and predatory birds were also much in evidence. From May 20 to May 27 observations were made at Wainwright, about one hundred miles west of Point Barrow. It was found that brown lemmings were also abundant here, under similar conditions of spring thaw. Several specimens of brown lemming were secured.

By May 27 the tundra appeared alive with lemmings in the vicinity of Point Barrow, wherever there were snow-free areas. Dead lemmings were much in evidence, scattered over the bare tundra and surrounding snow, and occasional aggregations of lemmings were found, which had probably been made by foxes. Figure 3 shows the appearance of the tundra at this time.

On May 28 Dr. Laurence Irving and the writer collected lemmings along the margins of a large marshy area about a mile south of Point Barrow. Hundreds of lemmings were observed, most of them escaping under the unmelted snow. About 25 dead animals were picked up, including three collared lemmings, the only ones of their species seen at this time. The latter weighed 57, 78, and 91 grams. Dying brown lemmings were seen occasionally. The apparently normal animals collected were taken with a shot gun, since otherwise they escaped beneath the snow.

One of the most impressive things observed was the congregation of predatory birds and mammals in the areas where lemmings were most abundant. Arctic foxes were numerous, and their tracks were everywhere in evidence around the open tundra areas. Many dogs came out from Barrow village to feed on the dead and dying lemmings. Owls were numerous, and pomarine jaegers were abundant. Glaucous gulls were 
present in smaller numbers over the tundra, although they were numerous along the coast.

Three living collared lemmings, the only ones seen on this date, were collected on May 29 where they were found among hundreds of brown lemmings. These animals weighed 12,31 , and 43 grams. The writer saw no conflicts between the animals of the two species; both occurred together in the same places, although collared lemmings were rare.

During the last days of May it was evident that larger brown lemmings were preponderant; apparently almost all breeding had ceased some weeks

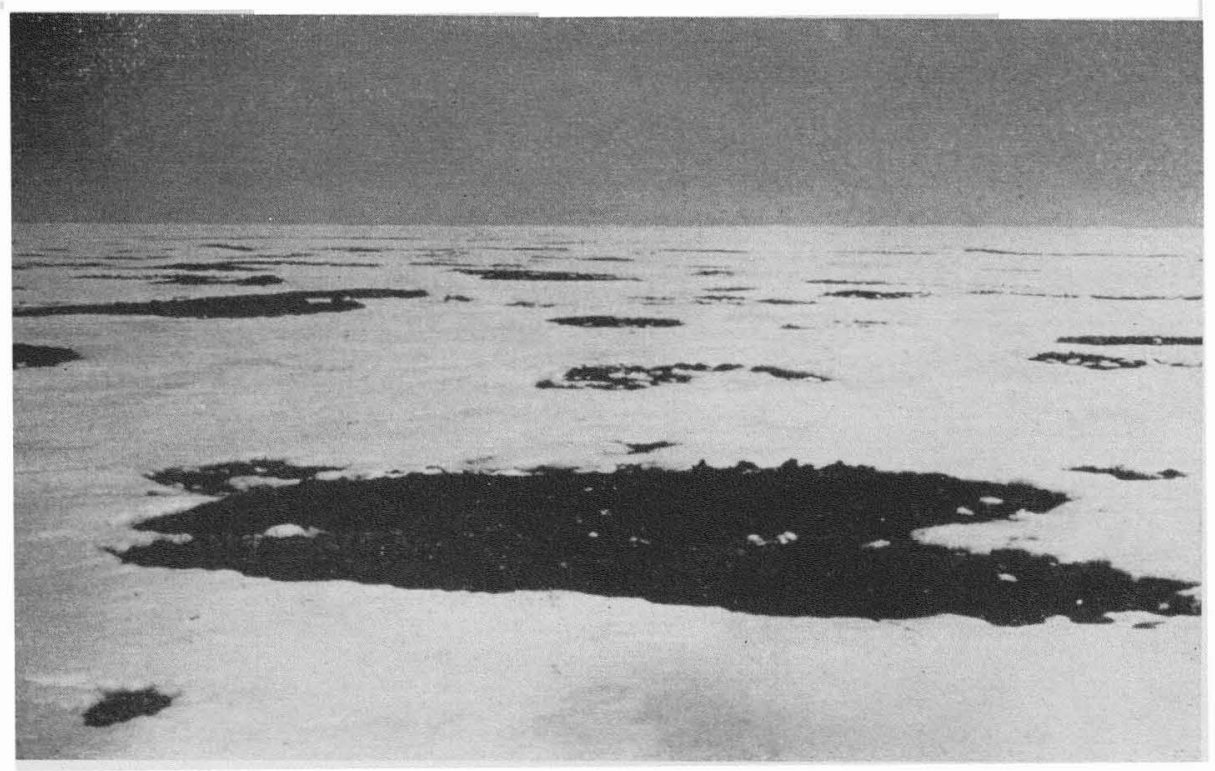

Fig. 3. Appearance of the tundra at the time of highest lemming density.

before. The average weight of 91 animals collected during this time was 60.8 grams ( 10.5 to 95 grams).

There was a rapid decrease in lemming numbers from the last few days of May until early June. By June 6 practically all the lemmings had disappeared, presumably having died. On June 6 only 2 living animals were noted, where a week before hundreds were seen in the same period of time. Dead and dying animals were also absent, apparently all having been consumed, mainly by the jaegers which closely patrolled the open areas where dead lemmings could be found. At this time there was estimated to be from 30 to 40 pomarine jaegers per square mile of tundra in the Point Barrow area. Eight of these birds were collected on June 2, and all had brown lemmings in their stomachs.

As far as it was possible to recognize, there was no further decline in lemming numbers after early June, although the scarcity of the animals made observations of any kind difficult. By the latter part of the month, 
when all snow had melted, evidence of the past abundance of the brown lemmings was everywhere. Nests were numerous, with large quantities of droppings around them (Fig. 4). There was a marked effect upon the tundra vegetation; in many places the tundra was practically denuded, and in other areas sedges cut during the fall or winter were washed up in windrows by the water from the melting snow (Fig. 5). The remaining lemmings were rarely seen, having established themselves in the relatively dry "owl mounds", where they apparently make burrows for the summer months. In favourable areas, particularly where sedges (Carex spp.) grew densely, typical runways were seen. Completely roofed-over runways were observed in certain areas where there was a dense lichen cover (Fig. 6). A few animals (Lemmus) were trapped in July by making runway sets with unbaited traps.

Intermittent observations during the remainder of the summer failed to disclose any change in the situation. Light snows in early October made it again possible to obtain some idea of lemming density (Fig. 7). Lemming tracks and other signs were scarce, and the observations made in the fall substantiated the opinion that lemmings were few. Snowy owls were very numerous during early October. On October 4 the writer estimated a density of about 8 to 10 owls per square mile in the vicinity of Point Barrow. These birds had almost entirely disappeared by the

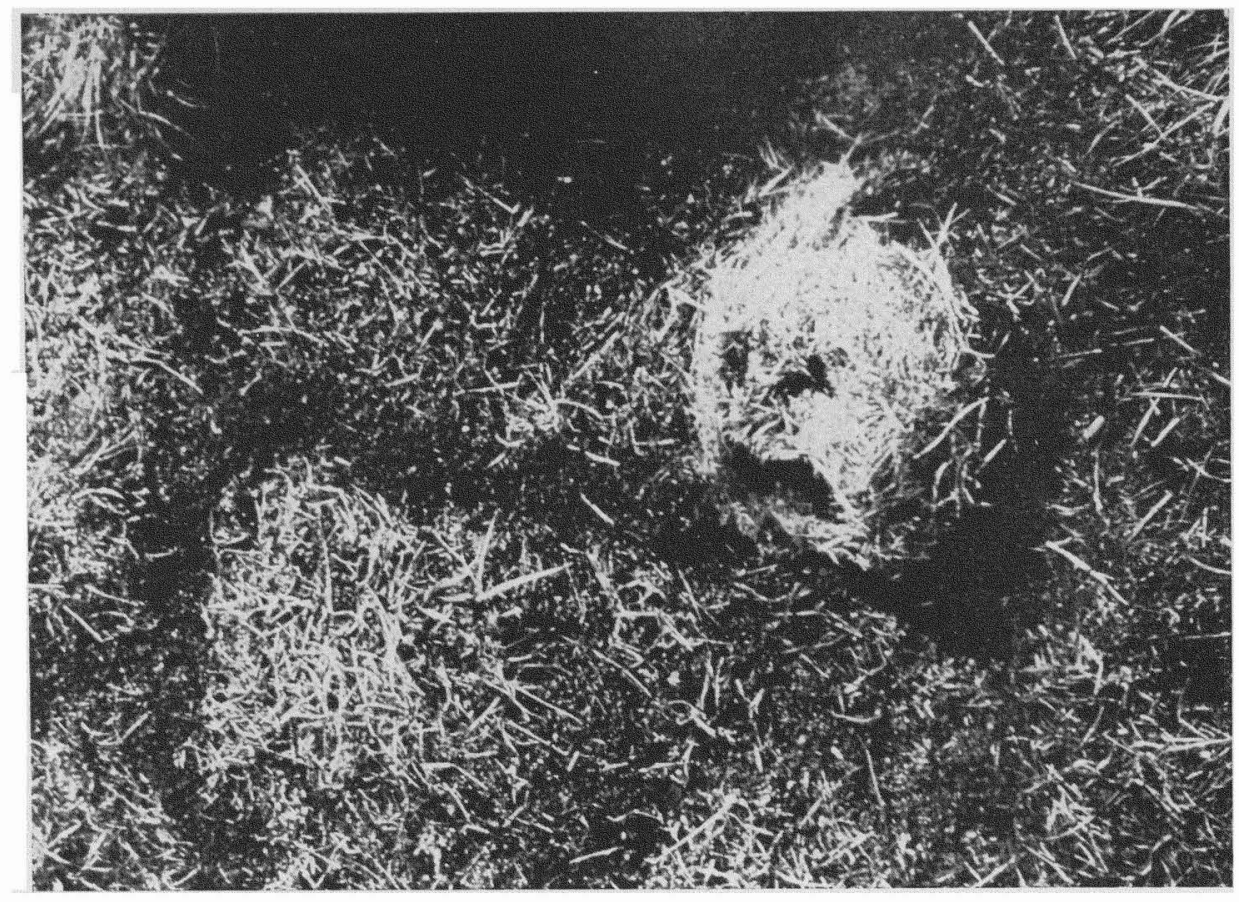

Fig. 4. Typical winter nest of the brown lemming, with abundant droppings, following the spring thaw of 1949. 
Rausch in ARCTIC (December 1950) 3(3). Copyright 1950, Arctic Institute of North America. Used by permission.

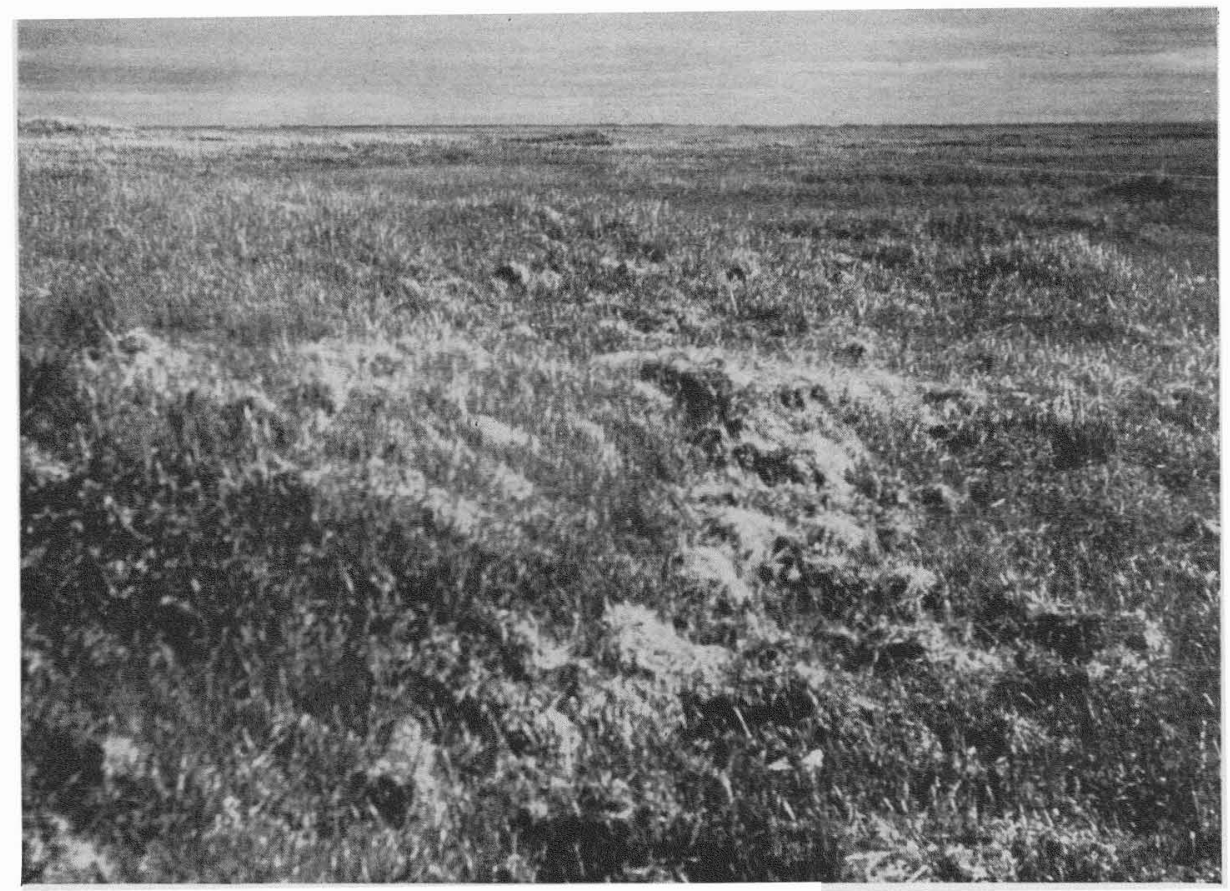

Fig. 5. Sedges cut by lemmings during 1949, washed into windrows by the spring thaw.

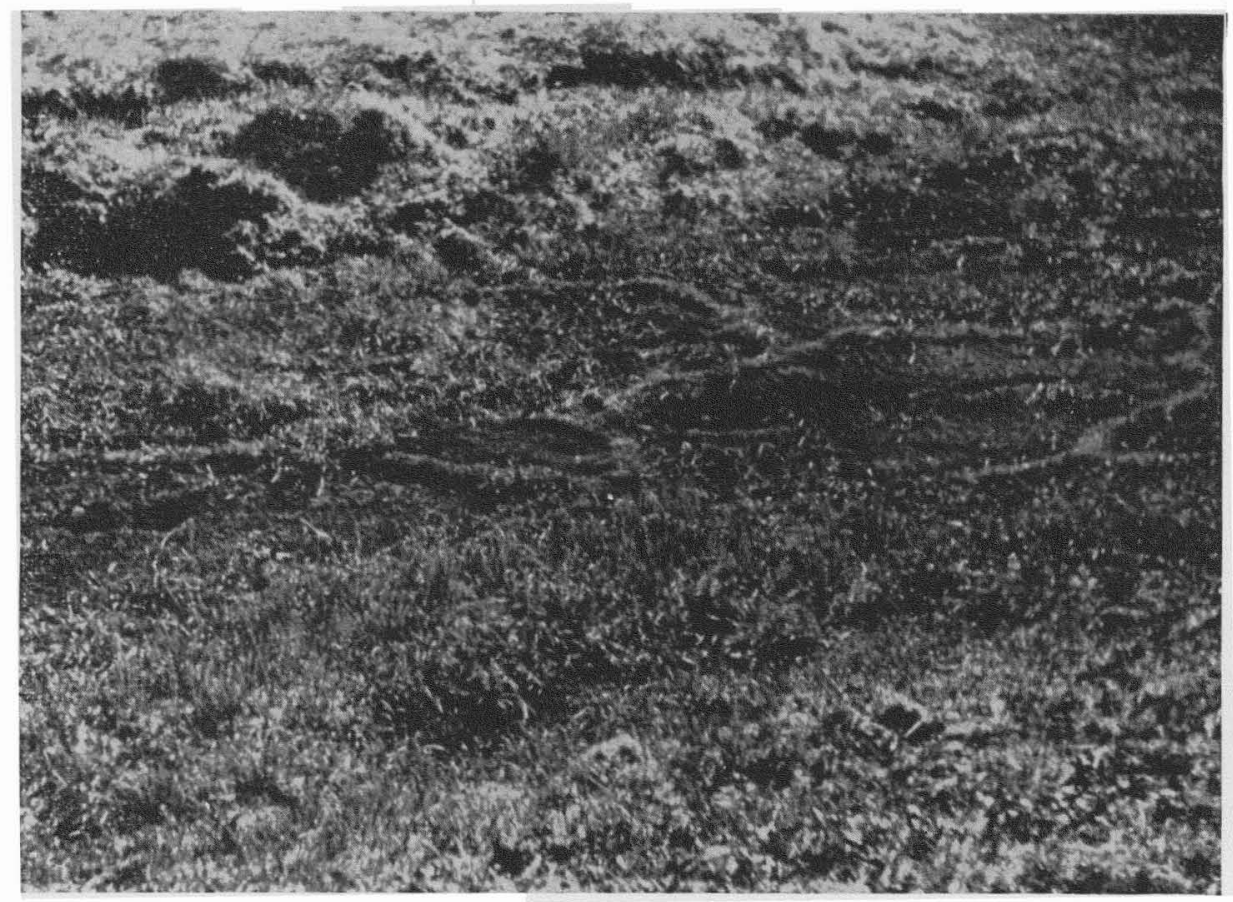

Fig. 6. Roofed-over runways of brown lemmings, near Point Barrow, summer of 1949. 


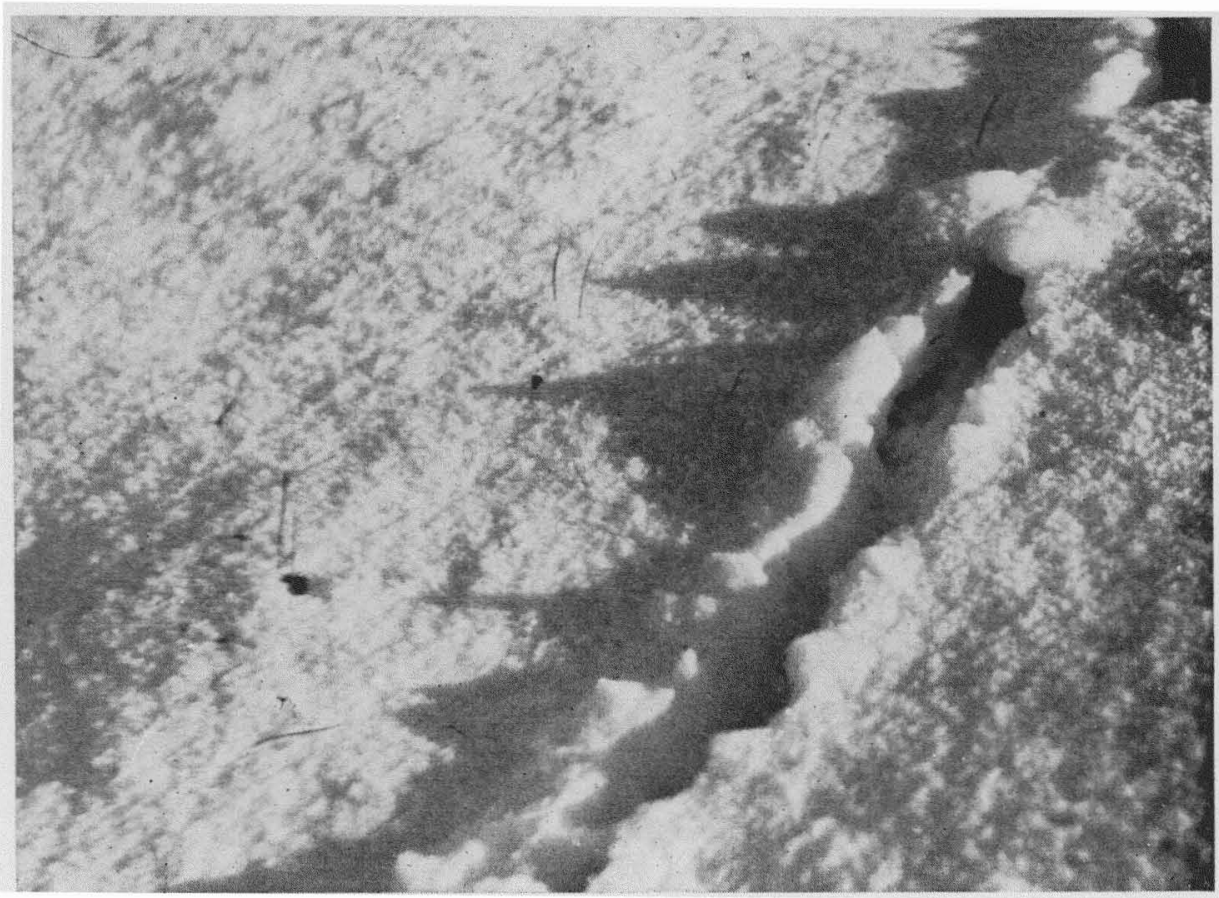

Fig. 7. Brown lemming runway as seen in the first light snow of autumn 1949, at Point Barrow.

end of the first week in November. The writer examined 99 owls collected after the decline had occurred, and found that 42 of these contained Lemmus remains in the stomach. A single Dicrostonyx skull was recovered. The bulk of these owls was collected during the month of October, 1949. From this it is obvious that the lemmings, though scarce, were by no means so rare that the owls were starving. The majority of these owls consisted of birds of the year, a high productivity having resulted from the earlier abundance of food.

\section{Comparative Observations in 1950}

In 1950 observations at Point Barrow were not begun until May 28, the time immediately preceding this having been spent inland beyond the limits of the previous lemming population peak. Extensive field observations in the vicinity of Point Barrow were made on May 29, and no sign of lemmings was discovered. In contrast to the conditions of the previous year, no snowy owls or jaegers were seen during the course of a trip which on the corresponding date in 1949 would have disclosed many of each. On May 30 there were four pomarine jaegers flying over an open lead about two miles off Point Barrow, but none was seen anywhere on the tundra. On June 4, when snow-free patches were numerous on the tundra, the writer travelled overland to a point about ten miles west of Point Barrow, and returned the same day. Some lemming droppings 
and a few tunnels in the snow were found, but no animals. It is noteworthy also that no snowy owls or jaegers were seen. On June 8, however, when the spring thaw was well advanced, E. L. Schiller and the writer observed 4 snowy owls and a few pomarine jaegers in an area of numerous peat hummocks just west of Point Barrow. Here there were a few lemming tracks, and two animals (Lemmus) were captured. Lemming droppings were rather abundant on those hummocks in which burrows were located. The examination of fresh owl pellets from this area showed that these birds were feeding exclusively on lemmings, and brown lemmings were found in the stomachs of several pomarine jaegers. Both species of birds, however, were much fewer than they had been the previous year.

The observations of Daniel Q. Thompson, who spent the summer of 1950 investigating the ecology of lemmings in the Point Barrow region, substantiate the conclusion of the writer that the lemmings were very scarce. Mr. Thompson's observations also support the conclusion that both owls and jaegers were rare in the Barrow region during 1950. Only one nest of the pomarine jaeger was found during the summer of 1950 , and only 4 owls, 2 young and 2 adults, were known to be in that vicinity. In contrast, the nests of both species were commonly observed during the early summer of 1949 .

\section{Discussion}

Years in which lemming populations are very high have been known in North America, although they seem rarely to give rise to the more spectacular migrations seen in northern Europe. A few migrations have been reported, but they have never been studied by biologists. Consequently, no good comparison can be made between the fluctuations in North America and those in Eurasia. According to the definitions of Kalela (1949), lemming population changes recorded in North America do not necessarily follow the same pattern as those in Eurasia. More information is needed regarding "Proliferationsperiode" in North America, and the occurrences leading up to high density and migration. Little information is available on lemmings in Alaska, but several studies have been made in Canada. Among these are the reports by Soper (1928), D. Chitty $(1939,1938)$, H. Chitty (1943), H. Chitty and D. Chitty (1945), Chitty and Elton (1937), Chitty and Nicholson (1942), Sutton and Hamilton (1932), and Shelford (1943). Flton (1942) has summarized much of this work.

An approximate 4-year cycle of abundance has been established for the lemming on the Arctic Slope of Alaska. The last "high" was during the spring of 1946. According to very reliable Eskimo, only the brown lemming shows such violent fuctuation in numbers. In this region the collared lenming does not appear to attain an unusual density. There 
are, however, reports of high densities of collared lemming in other parts of arctic North America. Sutton and Hamilton (1932, p. 65) described such an occurrence, and Soper (1928, p. 51) suggested that there might be an alteration of periods of abundance of the two species.

The true geographical extent of the high lemming density on the Arctic Coast of Alaska in 1949 could not be determined because of travel difficulties and the distances involved. However, incomplete observations allow at least some concept of this. Figure 1 gives the region over which it was known that the lemmings had reached a peak density. This extended from Point Lay, west of Point Barrow, to the Alaktak River, east of Point Barrow near Admiralty Bay. The animals were abundant to a distance of approximately 30 miles inland. Field work at Umiat on the Colville River, during the spring and summer of 1949, definitely established that lemmings were uncommon there. Only two specimens of Lemmmis were obtained, and one of these was taken from the stomach of a rough-legged hawk nesting on the Colville River bluffs. Also, there was no visible cvidence of any rodent activity attributable to lemmings, although certain other mouse-like rodents (Cletbrionomys rutilus; Microtus miurus; and $M$. oeconomus) were rather common in this region. Kalela (1949) has discussed the simultaneous occurrence of high population densities in various small rodents, as observed in northern Finland. Elton (1942) also discusses species other than lemmings. At the north edge of the Brooks Range, where the writer spent much time collecting mammals, both species of lemmings were taken, but both were uncommon (Rausch, 1950). According to the local Inland Eskimo, the lemmings never reach high population densities in this region.

The apparent relationship of lemming abundance and decline to snowy owl migration has long been recognized. Gross (1947) reviews some of the literature on this. There is no definite knowledge, however, as to how these are interrelated. The banding of snowy owls on the breeding grounds during years of high owl and lemming densities prior to any southward owl "invasion" would perhaps clearly establish the source of such migrating owls, and allow a better understanding of what is involved. Although, as mentioned above, it is evident that the owls had left the Arctic Coast by early November of 1949, it is not known where they went, nor what part they played in the invasion into the southern part of the continent. In any case, snowy owls were rare over the Arctic Slope of Alaska during the winter of 1949-50.

It is perhaps worthwhile to note that the large proportion of young birds in the owl population, resulting from a year of unusual nesting success, might have played an important part in this migration. The writer obtained more than 80 great horned owls (Bubo virginianus) trapped during the winters of 1946 and 1947 at the State Game Farm, Poynette, Wisconsin; of these practically all were immature birds which 


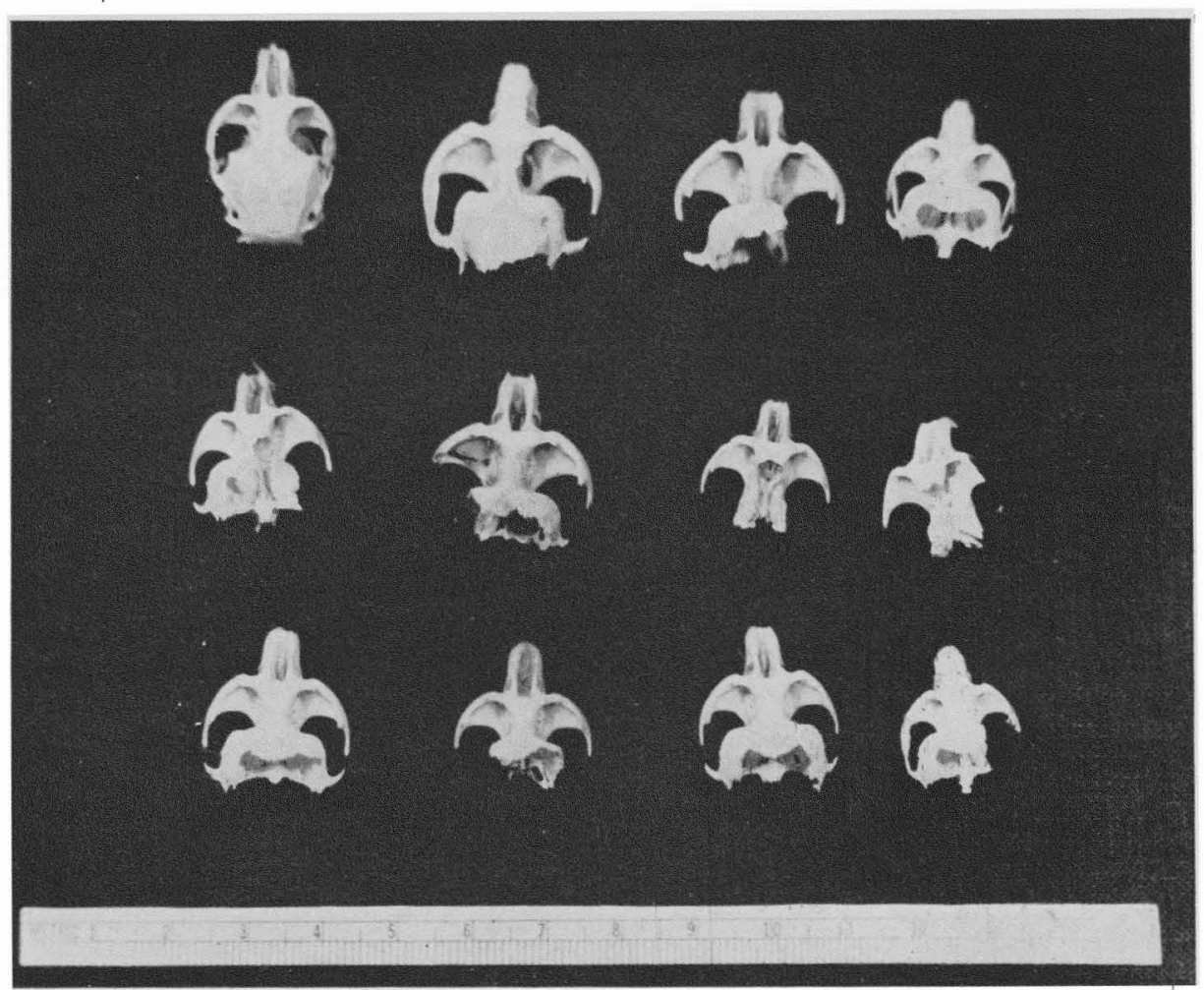

Fig. 8. Skulls of lemmings taken from snowy owl and pomarine jaeger stomachs, showing typical damage.

apparently were migrating prior to any localization. It could perhaps be suggested that an unstable owl population might result when many young are reared because of the unlimited food supply available during years of high lemming density, and that this might in some way contribute to the "invasion" phenomenon.

It is recognized by the Eskimo that jaegers become abundant during the years of high lemming density. The pomarine jaeger appeared early in May in the spring of 1949 , and became increasingly abundant up to the time of nesting. Although long-tailed and parasitic jaegers also were present they did not appear in the Barrow region until later, and were relatively few in number. In spite of the statements of McCabe and Racey (1944, p. 465 ), the jaegers are effective predators upon lemmings. The pomarine jaeger usually crushes the back of the skull of animals captured in the manner of the snowy owl. The writer has collected jaegers of all three species and has found no indication that their beaks are "weakly flexible" and "soft" as McCabe and Racey maintain. Figure 8 shows a collection of lemming skulls from owl and pomarine jaeger stomachs; the extent of damage is evident. Apparently the skull is not crushed when the lemming is picked up already dead.

Arctic foxes were unusually numerous during the winter of 1949-50. In addition to abundant tracks on the tundra and actual animals seen, the trapping results of the Coast Eskimo bear this out. The writer examined 
the stomachs of 79 foxes trapped up to January of 1950 . Of these, about 10 per cent contained lemmings; however, most were empty, so no reliable observations could be made. A moderately high fox population persisted into the summer of 1950.

According to the Eskimo, not only are "lemming years" particularly associated with snowy owl, jaeger, and arctic fox abundance, but also with good sea hunting. It was of interest that walrus hunting was unusually good in the Barrow region in the summer of 1949.

It is obvious that during the spring of 1949 the population of the brown lemming on the Arctic Coast of Alaska reached peak proportions, with a subsequent abrupt decline resulting from a heavy mortality. The suddenness of this decline found the writer unprepared for suitable pathological studies, so only superficial observations were made. It was noted that dying lemmings observed on the surface of the snow usually manifested considerable spasmodic or convulsive activity just prior to death. Although the presence of more obscure conditions was not determined, it was evident from the examination of numerous animals, secured both alive and after death, that there were no grossly visible lesions such as might be expected from bacterial infections. No effort was made to determine the presence of viruses or of other organisms.

Weber $(1950$, p. 553), in reference to this decline, stated that "When the lemmings increase too greatly they consume plants faster than they can grow in this cold climate and so starve themselves." While there is no doubt that the tundra vegetation was reduced by the lemmings, there is nothing tangible to indicate that the decline in numbers resulted from starvation. The relationship, if any, of vegetation reduction to lemming mortality can only be determined by controlled long-range observations.

Certain observations on the breeding and age composition of the population were derived from the animals examined during the spring of 1949. The absence of very young animals indicated little breeding for some weeks prior to the decline. The breeding condition of $139 \mathrm{lem}$ mings was determined prior to and during the time of decline, and no cvidence of reproductive activity was observed. Of these, 59 were females. A few females showed perforate vaginae, but none were pregnant, and there were no placental scars in the animals examined. The breeding condition of the males was not so readily determined, but apparently testicular development was not normal. The greatest testis length was $12 \mathrm{~mm}$., and descent was not complete.

Helminth parasite infections could not be considered abnormal, nor detrimental to the condition of the animals infected. In fact, parasitism was very light when compared with that usually observed in microtine rodents. As concluded for other species (Rausch and Tiner, 1949), there does not appear to have been any increase of helminth parasites under conditions of high population density. A summary of parasites found in 
the animals examined prior to and during the decline are shown in the following table.

\begin{tabular}{lclc} 
Host & Number examined & Parasite & Number infected \\
Lemmus & 139 & Hymenolepis borrida & 15 \\
& & Andrya primordialis & 4 \\
& & Paranoplocephala infrequens & 2 \\
& & Taenia temicollis (larval) & 1 \\
Dicrostonyx & \multirow{2}{*}{13} & Hymenolepis borrida & 2 \\
& & Andrya primordialis & 2 \\
& & Syphacia arctica & 5
\end{tabular}

Endoparasites recorded from lemmings in the Point Barrow region. All are cestodes but $S$. arctica, which is a nematode. Helminth names are according to the most recent nomenclature.

The factors involved in the high mortality which often follows high population densities of lemmings and other microtine rodents can only be determined by controlled long-term studies. These observations will be continued and, if circumstances permit, a carefully planned investigation of lemming mortality will be carried out during the next time of high lemming density. Presumably, this will occur during the spring of 1952.

\section{REFERENCES}

Chitty, D. 1938. "Canadian Arctic wildlife enquiry, 1936-37". J. Anim. Ecol. Vol. 7 , pp. $381-394$

1939. "Canadian Arctic wildlife enquiry, 1937-38". I. Anim. Ecol. Vol. 8, pp. 247-260.

Chitty, D., and M. Nicholson. 1942. "Canadian Arctic wildlife enquiry, 1940-41". J. Anim. Ecol. Vol. 11, pp. 270-287.

Chitty, D., and C. Elton. 1937. "Canadian Arctic wildlife enquiry, 1935-36". J. Anim. Ecol. Vol. 6, pp. 368-385.

Chitty, H. 1943. "Canadian Arctic wildlife enquiry, 1941-42". I. Anim. Ecol. Vol. 12, pp. 163-172.

Chitty, H., and D. Chitty. 1945. "Canadian Arctic wildlife enquiry, 1942-43". J. Anim. Ecol. Vol. 14, pp. 37-45.

Elton, C. 1942. 'Voles, mice and lemmings'. Oxford, pp. 1-496.

Gross, A. O. 1947. "Cyclic invasions of the snowy owl and the migration of 1945-1946". Auk. Vol. 64, pp. 584-601.

Kalela, O. 1949. "Über Fjeldlemming-Invasionen und andere irreguläre Tierwanderungen. Mit einer Übersicht der Kleinnagergradationen in Finnisch-Lappland 1900-1948". Ann. Zool. Soc. "Vanamo". Vol. 13, pp. 1-90.

McCabe, T. T., and K. Racey. 1944. "The parasitic jaeger". $A u k$, Vol. 61, pp. 465-466.

Rausch, R. 1950. "Notes on microtine rodents from the Brooks Range, Arctic Alaska". J. Wash. Acad. Sci. Vol. 40, pp. 133-136.

Rausch, R., and J. D. Tiner. 1949. "Studies on the parasitic helminths of the North Central States. II. Helminths of voles (Microtus spp.). Preliminary report." Anter. Midl. Nat. Vol. 41, pp. 665-694.

Shelford, V. E. 1943. "The abundance of the collared lemming (Dicrostonyx groenlandicus (tr.) var. Richardsoni Mer.) in the Churchill area, 1929 to 1940". Ecology, Vol. 24, pp. 472-484.

Soper, J. D. 1928. "A faunal investigation of southern Baffin Island". Bull. Nat. Mus. Can. No. 53 (Biol. Ser. No. 15), pp. 1-143.

Sutton, G. M., and W. J. Hamilton. 1932. 'The exploration of Southampton Island, Hudson Bay'. Part II, Zoology. Section 1, "The mammals of Southampron Island". Mem. Carnegie Mus. Vol. 12, pp. 1-111.

IVeber, $X$. 1950. "The role of lemmings at Point Barrow, Alaska". Science, Vol. 111, No. 2890, pp. 552-553. 